zją do podzielenia się wynikami najnowszych badań, wymiany myśli i nawiązania wielu kontaktów. $Z$ pewnością zaowocują ożywioną międzynarodową współpracą naukową, tym bardziej że zgłoszone referaty będą utrwalone i szerzej dostępne - zostaną w formie artykułów zamieszczone w księdze ku czci Jubilata. Podczas wystąpień, a zwłaszcza w toku licznych dyskusji - krótkich na salach obrad, za to długich w kuluarach - wskazywano, że studia z zakresu prawa rzymskiego nie sprowadzają się do czysto historycznych rozważań, lecz stanowią świetną podstawę do poszukiwania rozwiązań wielu współczesnych problemów prawnych. Ten sposób myślenia wydaje się zdobywać coraz większe poparcie w światowej romanistyce.

Franciszek Longchamps de Bérier*

\title{
I Sesja Międzynarodowej Szkoły Prawa Rzymskiego WARSZAWA 12-24 WRZEŚNIA 2001 ROKU
}

Odradzanie się studiów prawa rzymskiego w krajach dawnego obozu socjalistycznego, a zwłaszcza w byłym Związku Sowieckim, odbywa się spontanicznie. Zaangażowani są w nie historycy, filologowie oraz cywiliści, gdyż brak odpowiednio przygotowanej kadry wykładowców tego przedmiotu. Okazało się to wyraźnie podczas konferencji w Moskwie w listopadzie 1997 roku, zorganizowanej przez Centrum studiów nad prawem rzymskim, Wydział Prawa Uniwersytetu im. Łomonosowa w Moskwie, oraz podczas Kolokwiów romanistów Europy środkowo-wschodniej i Włoch organizowanych (w Rzymie w dniach 4-6 grudnia 1998 i we Władywostoku w dniach 5-7 października 2000) przez Centro per gli studi su Diritto romano e sistemi giuridici del Consiglio Nazionale delle Ricerche kierowane przez Pierangelo Catalano z Uniwersytetu „La Sapienza" w Rzymie. Widząc potrzebę odpowiedniego przygoto-

\footnotetext{
* Uniwersytet Warszawski.
} 
wania romanistów prof. Witold Wołodkiewicz wysunął ideę powołania Międzynarodowej Szkoły Prawa Rzymskiego (MSPR). Została ona pozytywnie przyjęta przez uczestników konferencji w Moskwie, a następnie w Rzymie. Ostateczny projekt powołania MSPR został przyjęty $\mathrm{z}$ uznaniem i poparty przez uczestników konferencji we Władywostoku. Celem Szkoły jest pomoc w kształceniu kadr naukowych $z$ zakresu prawa rzymskiego i metod jego nauczania oraz umożliwienie kontaktów romanistów z krajów Europy Środkowo-Wschodniej i ze Wspólnoty Niepodległych Państw z przedstawicielami nauki światowej prawa rzymskiego, głównie włoskiej.

Dzięki staraniom prof. Witolda Wołodkiewicza I Sesja Międzynarodowej Szkoty Prawa Rzymskiego odbyła się w ramach Międzynarodowej Szkoły Humanistycznej Europy Środkowo-Wschodniej prowadzonej przez Ośrodek Badań nad Tradycją Antyczną Uniwersytetu Warszawskiego (OBTA-UW) przy współudziale Katedry Prawa Rzymskiego i Antycznego UW w dniach 12-24 września 2001 roku.

W posiedzeniu I Sesji MSPR wzięło udział 14 uczestników - z Federacji Rosyjskiej 9 osób, z Ukrainy 3 osoby, z Litwy 1 osoba, z Chorwacji 1 osoba. Byli to młodzi pracownicy naukowi z uniwersytetów i szkół prawniczych, mający wykształcenie prawnicze lub historyczne, a wykładający prawo rzymskie w Moskwie, Petersburgu, Chabarowsku, Krasnojarsku, Saratowie, Syktywkarze (Republika Komi), Odessie, Kijowie, Lwowie, Wilnie i Osijeku (Chorwacja).

Wykładowcami MSPR byli profesorowie prawa rzymskiego z uniwersytetów zagranicznych: z Włoch (4 osoby), z Niemiec (2 osoby), z Ukrainy (1 osoba) oraz $\mathrm{z}$ uniwersytetów polskich: z Warszawy (UW oraz UKSW - 7 osób), z Łodzi (1 osoba), z Lublina (UMCS - 1 osoba).

Językiem wykładowym był włoski (niektóre wykłady odbywały się po rosyjsku). Całość obrad była tłumaczona na język rosyjski. Uczestnicy MSPR brali również udział codziennie w lektoracie języka włoskiego. Wybór języka włoskiego, jako języka MSPR, wynikał z faktu, że nauka włoska prawa rzymskiego ma wciąż czołowe znaczenie. W perspektywie uczestnicy mają również szansę uzyskać stypendia we Włoszech. 
Wykłady dotyczyły następujących zagadnień:

- Metodologia badań nad prawem rzymskim i zastosowanie w nich elektronicznych baz danych (prof. Nicolo Palazzolo, dyrektor Istituto per la Documentazione Giuridica del Centro Nazionale delle Ricerche -6 godz.);

- Paremie prawne i ich stosowanie w prawie europejskim (prof. Andreas Wacke, z Uniwersytetu w Kolonii - 2 godz.);

- Reguły prawne $w$ jurysprudencji rzymskiej okresu republiki (dr Agnieszka Kacprzak, z Uniwersytetu Warszawskiego 1 godz.);

- Lex Aquilia - podstawą formowania współczesnej odpowiedzialności deliktowej (prof. Andreas Wacke - 2 godz.);

- Prawo rzymskie a obrót handlowy (dr Jerzy Krzynówek, z Uniwersytetu Warszawskiego - 1 godz.);

- Prawo rzymskie a świat współczesny (prof. Witold Wołodkiewicz, UW - 3 godz.);

- Prawo rzymskie w perspektywie tworzenia zunifikowanego prawa europejskiego (prof. Antonio Masi, z Uniwersytetu „La Sapienza" w Rzymie - 3 godz.);

- Rzymskie prawo spadkowe i rzeczowe a prawo współczesne (prof. Antonio Masi - 3 godz.);

- Rzymska literatura nieprawnicza jako źródło poznania prawa rzymskiego (prof. Jan Zabłocki, z Uniwersytetu Kardynała Stefana Wyszyńskiego w Warszawie - 3 godz.);

- Recepcja prawa rzymskiego w tworzeniu prawa prywatnego w Europie (prof. Ewgen Charitonow, z Państwowej Akademii Prawa w Odessie -3 godz.);

- Rzymskie prawo karne (prof. Luigi Garofalo, z Uniwersytetu w Padwie - 3 godz.);

- Zobowiązania kontraktowe (prof. Luigi Garofalo - 3 godz.);

- Rzymskie prawo osobowe i rodzinne (prof. Maria Zabłocka, z Uniwersytetu Warszawskiego - 3 godz.);

- Prawo rzymskie w systemie dyscyplin prawniczych (prof. Tomasz Giaro, z Max Planck Institut für Europäische Rechtsgeschichte we Frankfucie nad Menem - 3 godz.). 
Ponadto odbyły się dwa posiedzenia „okrągłego stołu”: pierwsze poświęcone Znaczeniu prawa rzymskiego $w$ dogmatyce $i$ filozofii prawa (wprowadzenie prof. Witold Wołodkiewicz oraz prof. Tomasz Giaro), drugie poświęcone Recepcji prawa rzymskiego (wprowadzenie prof. Juliusz Bardach z Uniwersytetu Warszawskiego oraz prof. Ewgen Charitonow z Państwowej Akademii Prawa w Odessie i prof. Marek Kuryłowicz z Uniwersytetu Marii Curie-Skłodowskiej w Lublinie).

Uczestnicy Szkoły, podczas wizyty w Sądzie Najwyższym, zapoznali się z paremiami rzymskimi umieszczonymi na kolumnach gmachu Sądu. Zostali też przyjęci przez Pierwszego Prezesa SN prof. Lecha Gardockiego.

Uczestnicy otrzymali dyplomy Międzynarodowej Szkoly Prawa Rzymskiego w Warszawie z rąk prof. Jerzego Axera Dyrektora OBTA oraz prof. Witolda Wołodkiewicza Dyrektora MSPR.

II Sesja Międzynarodowej Szkoły Prawa Rzymskiego planowana jest na wrzesień 2002 roku.

Jan Zabłocki*

\section{PolsKo-NIEMIECKIE KolOKWIUM \\ PRAWNIKÓW ADMINISTRATYWISTÓW \\ WARSZAWA 19-23 WRZEŚNIA 2001 ROKU}

Od wielu lat, w cyklach dwuletnich, odbywają się spotkania, które przyjęły formułę konferencji naukowych polskich i niemieckich naukowców, specjalistów w zakresie prawa administracyjnego. Stały się one płaszczyzną wymiany poglądów i doświadczeń na temat najbardziej aktualnych i wzbudzających kontrowersje zagadnień z kręgu zainteresowań administratywistów. Walor owych spotkań podnosi okoliczność, iż dyskusje prowadzone $w$ ich trakcie mają często charakter prawnoporównawczy oraz ukazują aktualny stan

\footnotetext{
* Uniwersytet Kardynała Stefana Wyszyńskiego.
} 